\title{
DOMESTICATION TECHNIQUE OF COMMERCIALLY IMPORTANT FRESHWATER MUD EEL, Monopterus cuchia (HAMILTON, 1822)
}

\author{
NUSRAT JAHAN $^{1}$, MOHAMMAD ABDUS SALAM $^{1 *}$, ALI AHSAN $^{1,2}$, MOHAMMAD LUTFAR RAHMAN $^{1}$, \\ SULAV INDRA PAUL ${ }^{3}$, SIMON KUMAR DAS ${ }^{4 *}$ and SABUJ KANTI MAZUMDER ${ }^{1}$ \\ ${ }^{1}$ Department of Genetics \& Fish Breeding, Faculty of Fisheries, \\ Bangabandhu Sheikh Mujibur Rahman Agricultural University, Gazipur-1706, Bangladesh \\ ${ }^{2}$ Department of Biological, Geological, and Environmental Sciences, Cleveland State University, USA \\ ${ }^{3}$ Department of Biotechnology, Faculty of Agriculture, \\ Bangabandhu Sheikh Mujibur Rahman Agricultural University, Gazipur-1706, Bangladesh. \\ ${ }^{4}$ School of Environmental and Natural Resource Sciences, Faculty of Science and Technology, \\ Universiti Kebangsaan Malaysia, 43600 UKM Bangi Selangor, D.E., Malaysia \\ *E-mail: simon@ukm.edu.my,salam_aqua@yahoo.com
}

Accepted 12 June 2020, Published online 30 June 2020

\begin{abstract}
The research was conducted to develop the domestication technique of Monopterus cuchia collected from Sherpur district, Bangladesh. A total of 300 young M. cuchia (average $95 \pm 6.4 \mathrm{~g}$ ) was reared under nine treatments as earthen pond with dead fish (EpDf), earthen pond with live fish (EpLf), earthen pond with formulated feeds (EpFf), mud treated plastic tank with dead fish (PmDf), mud treated plastic tank with live fish (PmLf), mud treated plastic tank with formulated feeds (PmFf), plastic tank with dead fish (PtDf), plastic tank with live fish (PtLf), and plastic tank with formulated feeds (PtFf) with three replicates each. Size of each earthen pond was $1 \mathrm{~m}^{3}$ and plastic circular tank was $0.322 \mathrm{~m}^{3}$. Stocking density was maintained at 10 fish in each replicate by random selection. Survival, weight gain (WG), specific growth rate (SGR\%/day), feed conversion ratio (FCR), feed conversion efficiency (FCE), and protein efficiency ratio (PER) were measured. The best survival (100 \pm 0 ), WG (61.17 \pm 1.83$)$, SGR (0.118 \pm 0.026$)$, FCR (2.44 \pm 0.17$)$, FCE $(35.75 \% \pm 2.90)$, and PER $(1.75 \pm 0.14)$ were obtained in EpLf, which was significantly higher $(\mathrm{P}<0.05)$ than others. This is the first report of domestication of $M$. cuchia and indicates that earthen pond with live fish might be suitable for domestication of M. cuchia.
\end{abstract}

Key words: Earthen pond, SGR, FCR, Monopterus cuchia

\section{INTRODUCTION}

The biomass, ecosystems and water flow of the rivers and wetlands of Bangladesh are being interrupted due to the changing of climate and global warming. As a result, several fish species those were previously available in natural water bodies are now enlisted as vulnerable species. Monopterus cuchia is known as freshwater air breathing, swamp mud eel locally known as Kuchia or Kucha, belongs to the Family Synbranchidae. Unregulated collection, natural and man-made interruption is responsible for habitat destruction of M. cuchia. It is generally found in the freshwater of Bangladesh, Pakistan, Northern and Northeastern

\footnotetext{
* To whom correspondence should be addressed.
}

India and Nepal (Jhingran \& Talwar, 1991). Generally, the small ethnic communities of Bangladesh earn their livelihood by $M$. cuchia collection. The ethnic people also use this fish for treatment of various ailments. Fresh blood of this fish can cure weakness, anemia and asthma of human being (Kakati et al., 2006) as well as this fish also cures anemia, piles and diabetes (Saikia \& Ahmed, 2012). Moreover, the caloric value of eel flesh is

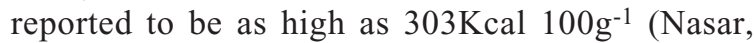
1997). Vitamins and essential amino acids including alanine, arginine, glycine, histidine, leucine and methionine had also been reported from this fish (Mishra et al., 1977).

Naturally collected mud eel is being exported from Bangladesh to South East Asia and different countries of Europe but not yet been given enough 
attention. By improving culture management, domestication and developing successful induced breeding technique, mud eel could be an alternative option for poor people. This species can contribute in an immerging trade for fishery product traders. Considering the increasing demand in the international markets (FAO, 2005), eel fishery has been gaining popularity among the coastal community of greater Khulna and Chattagram regions as well as greater Mymensingh, Sylhet and Cumilla regions in Bangladesh.

Although it is very difficult to introduce the culture technologies of this species commercially due to scarcity of fry and fingerlings, the collection of fry and fingerlings from natural waters could be potential for pond aquaculture. A decrease in the availability of mud eels and increase in demand for eels in the market place will inevitably lead both to increased prices and decreased natural eel stocks. The vicious spiral could be stopped through the development of techniques to mass production of mud eels through aquaculture. Although there are some other commercially important freshwater eels like M. albus, Anguilla anguilla, A. japonica etc. (Pankhurst, 1982; Tanaka et al., 2003; Park et al., 2020) that have been domesticated and used for artificial breeding throughout the world. However, there was no report on domestication and induced breeding of M. cuchia. Therefore, the aim of this study was to develop the domestication technique of this commercially important eel fish.

\section{MATERIALS AND METHODS}

\section{Collection of fish and stocking}

A total of 300 young M. cuchia fish (average weight $95 \pm 6.4 \mathrm{~g}$ ) were collected from the local fishermen of Sherpur district, Bangladesh. The fish were transported to the experimental site of the department of the Genetics and Fish Breeding Laboratory, Bangabandhu Sheikh Mujibur Rahman Agricultural University, Bangladesh carefully. The fishes were kept in thirty oxygenated plastic bags, which were filled with two-third of oxygen and onethird of freshwater. Before stocking, each tank was disinfected thoroughly and filled up with freshwater. The earthen ponds were also checked for water carrying capacity and checked carefully if there was any hole in the bottom of the pond. Stocking density was maintained at 10 -fishes/ pond and tank by random selection. The weight $(\mathrm{g})$ was measured by using an electric balance (Digital Balance, TANITA KD-160).

\section{Experimental setup}

The experiment was designed in nine treatments viz earthen pond with dead fish (EpDf), earthen pond with live fish (EpLf), earthen pond with formulated feeds (EpFf), mud treated plastic tank with dead fish (PmDf), mud treated plastic tank with live fish (PmLf), mud treated plastic tank with formulated feeds (PmFf), plastic tank with dead fish (PtDf), plastic tank with live fish (PtLf) and plastic tank with formulated feeds (PtFf). Each treatment had three replications. The size of the experimental earthen ponds were $(1 \mathrm{~m} \times 1 \mathrm{~m} \times 1 \mathrm{~m})$ each whereas plastic circular tanks were $(3.14 \times 0.38 \mathrm{~m} \times 0.38 \mathrm{~m} \times$ $0.71 \mathrm{~m}$ ) each for this experiment. The sheets of polythene was spread at the bottom of pond to prevent their burrowing activities of mud eel and the water depth was maintained at $10 \mathrm{~cm}$ (Salam et al., 2009) in all the ponds and tanks. Layers of water hyacinths were placed on the surface of earthen ponds to prevent excess heat from sunlight. Each tank was designed with good inlet and outlet system for facilitating at least $50 \%$ water exchange weekly. Similarly, each pond also has an inlet and an outlet system for facilitating at least $50 \%$ water exchange weekly. The experiment was conducted for a period of six months.

\section{Experimental feed}

Proximate composition of the experimental feeds was analyzed by following standard method of Association of Official Analytical Chemists (AOAC, 1980) in the Nutrition Laboratory of Faculty of Fisheries, BSMRAU, Bangladesh (Table 1). Fry of Oreochromis niloticus were applied as small live fish and small dead fish food. Based on the results, protein content of different experimental feeds including small dead fish, small live fish and formulated feeds were $20.30 \%, 20.30 \%$ and $30.00 \%$, respectively.

The formulated feeds in the form of pellet (dry matter basis) feeds were prepared from locally

Table 1. Proximate composition of the different feeds for domestication of $M$. cuchia

\begin{tabular}{lcccccc}
\hline Food items & Moisture (\%) & Ash (\%) & Crude lipid (\%) & Protein (\%) & Crude fiber (\%) & NFE* $\left.^{*} \%\right)$ \\
\hline Small live fish & 32.10 & 15.40 & 9.30 & 20.30 & 0.70 & 22.20 \\
Small dead fish & 31.38 & 15.30 & 9.50 & 20.30 & 0.72 & 21.60 \\
Formulated feed & 20.0 & 14.3 & 6.90 & 30.0 & 1.40 & 21.00 \\
\hline
\end{tabular}

* Nitrogen free extract calculated as: $100-\%$ (Moisture + Protein + Lipid + Ash + Crude fiber). 
Table 2. Composition of experimental feed for domestication of $M$. cuchia (dry matter basis)

\begin{tabular}{lc}
\hline Ingredients & Inclusion level (\%) \\
\hline Mustard oil cake & 15 \\
Fish meal & 55 \\
Rice bran & 11 \\
Wheat bran & 14 \\
Atta & 4.7 \\
Vitamin & 0.1 \\
Salt & 0.2 \\
\hline
\end{tabular}

available raw materials and their percentage composition is shown in Table 2. Fish were fed $1 \%$ of the body weight once daily at 5.00 PM. Sampling was done monthly.

\section{Sampling of fish}

In order to observe the growth rate and health condition of the fish, sampling was done monthly. During sampling, all fish from each tank and earthen ponds were caught manually and kept in plastic bucket after lowering the water level. At the time of each sampling, all the tanks were washed with potassium permanganate and the tanks were refilled with new water. The weight $(\mathrm{g})$ was measured by using an electric balance (Digital Balance, TANITA KD-160).

\section{Parameters studied for growth and feed utilizations of $\mathrm{M}$. cuchia}

During the period of experiment, the following growth parameters were measured according to Hasan et al. (2018).

Weight gain $(\mathrm{g})$

$=$ Mean final weight - mean initial weight

Specific growth

$\operatorname{SGR}(\% /$ day $)=\frac{\operatorname{Loge}_{2}-\operatorname{LogeW}_{1}}{T_{2}-T_{1}} \times 100$

Where,

$\mathrm{W}_{1}=$ the initial live body weight $(\mathrm{g})$ at time $\mathrm{T}_{1}$ (day)

$\mathrm{W}_{2}=$ the final live body weight $(\mathrm{g})$ at time $\mathrm{T}_{2}$ (day)

Feed conversion ratio (FCR)

$=$ Feed fed $/$ Gain in weight of fish

Feed conversion efficiency $(\mathrm{FCE} \%)=$

[(Gain in wet weight of fish / Feed Fed $)] \times 100$

Protein Efficiency Ratio (PER) =

Increment in body weight $(\mathrm{g}) /$ Protein intake $(\mathrm{g})$

\section{Water quality parameters}

All water quality parameters such as temperature, dissolve oxygen (DO) and $\mathrm{pH}$ were maintained strictly throughout the experimental period, as $M$. cuchia is very sensitive to changes in habitat. The water quality parameters were measured in the morning 9:00 A.M and in the evening at 17:00 P.M from the different corners of the tanks and earthen ponds. Temperature, $\mathrm{DO}$ and $\mathrm{pH}$ of water in each replication under each treatment were recorded every day according to Sayeed et al. (2015). Temperature was recorded by using a Celsius thermometer, DO was measured by a digital DO meter (LUTRON PDO-519, TAIWAN) and pH was measured by a portable digital $\mathrm{pH}$ meter (EZODO, pH 5011).

\section{Statistical analysis}

All data (weight gain, specific growth rate, survival, FCR, FCE and PER) were analyzed using two-way analysis of variance (ANOVA) with normality and homogeneity test followed by Duncan's Multiple Range Test to test the significant results $(\mathrm{P}<0.05)$ between means. Standard error $( \pm \mathrm{SD})$ was calculated to identify the range of means. All the data were analyzed using the software SPSS v 16.

\section{RESULTS}

Effects of different habitats and feeds on growth and feed utilizations for domestication of $M$. cuchia

\section{Weight gain}

During the experimental period, treatments EpDf, EpLf, EpFf, PmDf, PmLf and PmFf showed significant $(\mathrm{P}<0.05)$ weight gain, whereas PtDf, PtLf and PtFf showed slight weight loss, which indicates that suitable habitat may affect the balanced growth (Figure 1). However, significantly $(\mathrm{P}<0.05)$, the highest WG was obtained in EpLf than any other treatments (Figure 1), implying that the earthen ponds with small live fish is appropriate habitat for domestication of M. cuchia.

\section{Specific growth rate}

The SGR was significantly $(\mathrm{P}<0.05)$ higher in EpDf, EpLf and EpFf than any other treatments while the lowest was observed in PtDf, PtFf and PtFf, indicating that earthen ponds can affect the growth performance of $M$. cuchia by providing an appropriate rearing environment (Figure 2). Moreover, significantly $(\mathrm{P}<0.05)$ the highest SGR was in EpLf than other treatments (Figure 2) indicating that earthen pond with live food might be suitable for domestication of M. cuchia.

\section{Survival}

Significantly $(\mathrm{P}<0.05)$, the highest survival was in treatments, EpDf, EpLf and EpFf than any others (Figure 3), implying that the earthen ponds might 


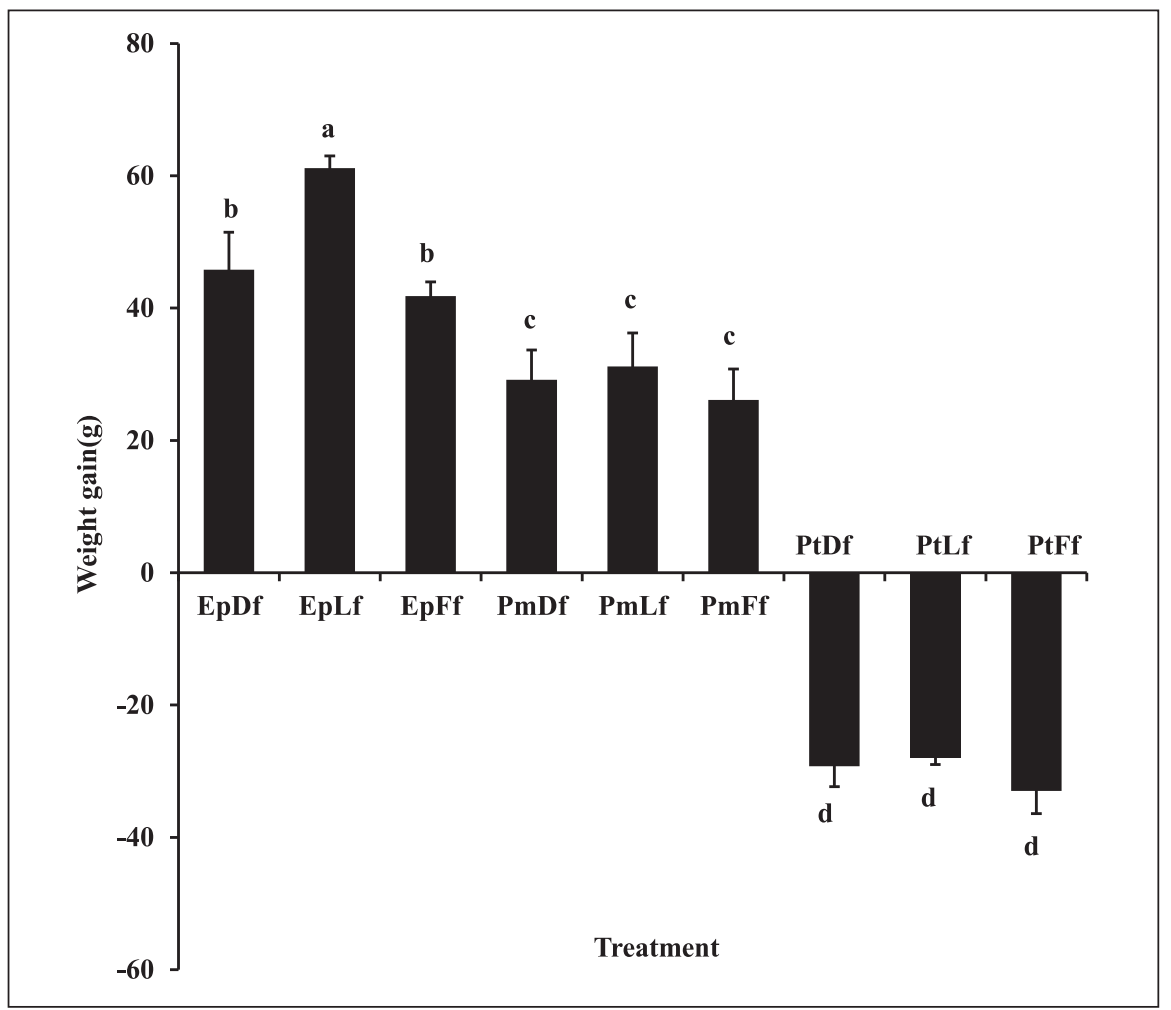

Fig. 1. Effects of different treatments on body weight gain of $M$. cuchia for domestication. Different letters indicate significant variations in weight gain fish in different treatments $\mathrm{P}<0.05$. Error bar $= \pm \mathrm{SD}$.

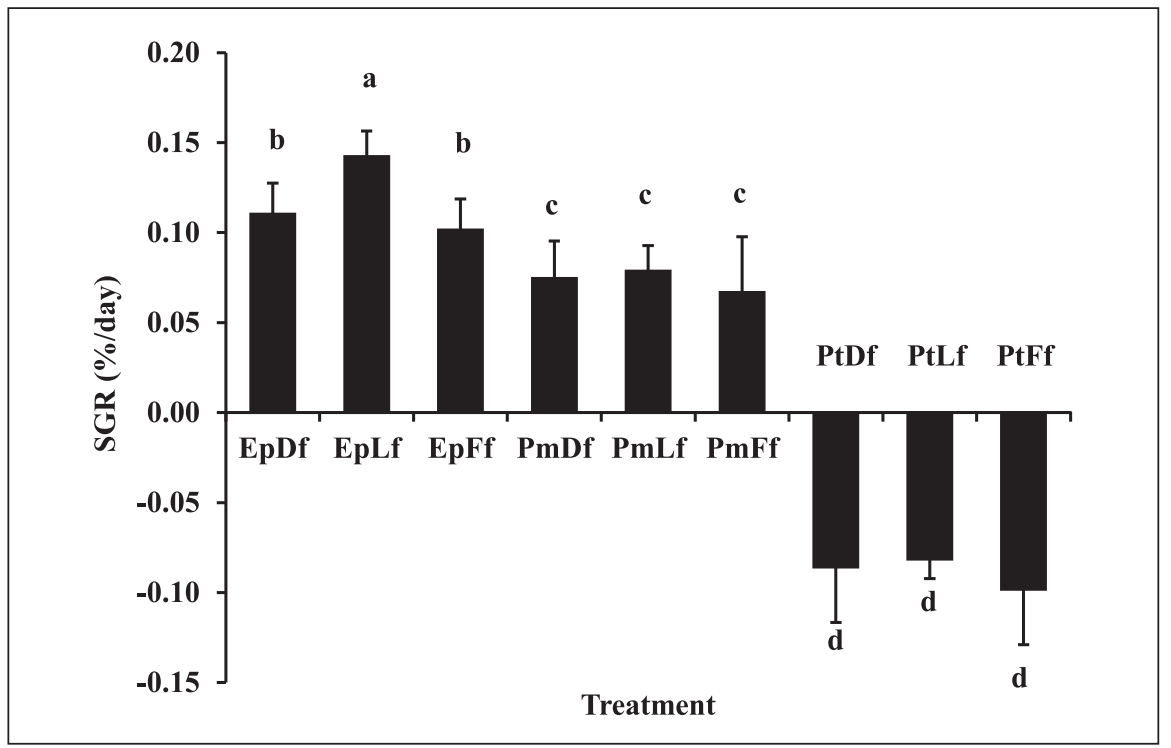

Fig. 2. Effects of different treatments on SGR (\%/day) of M. cuchia for domestication. Different letters indicate significant variations in weight gain fish in different treatments $\mathrm{P}<0.05$. Error bar $= \pm \mathrm{SD}$.

be suitable for survival of $M$. cuchia. However, there was no significant $(\mathrm{P}>0.05)$ difference among the treatments EpDf, EpLf and EpFf (Figure 3), suggesting that rearing mud eel in earthen ponds with small dead fish, small live fish and formulated feed might enhance the survival rate of fish.

\section{Feed conversion ratio}

The value of FCR was significantly $(\mathrm{P}<0.05)$ lower in EpDf, EpLf and EpFf than PmDf, PmLf and PmFf (Figure 4), indicating that M. cuchia consumed and assimilated feed efficiently in the earthen ponds. In addition, significantly $(\mathrm{P}<0.05)$ the 


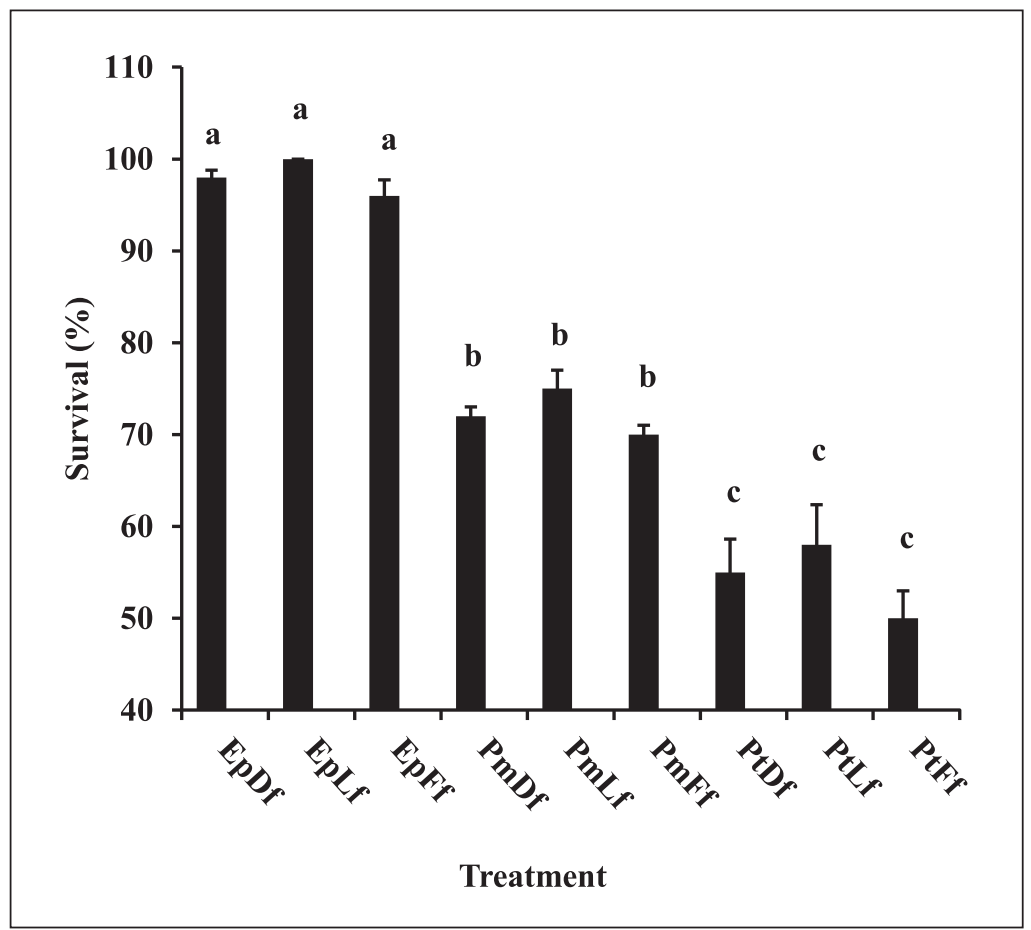

Fig. 3. Effects of different treatments on survival of $M$. cuchia for domestication. Different letters indicate significant variations in survival fish in different treatments $\mathrm{P}<0.05$. Error bar $= \pm \mathrm{SD}$.

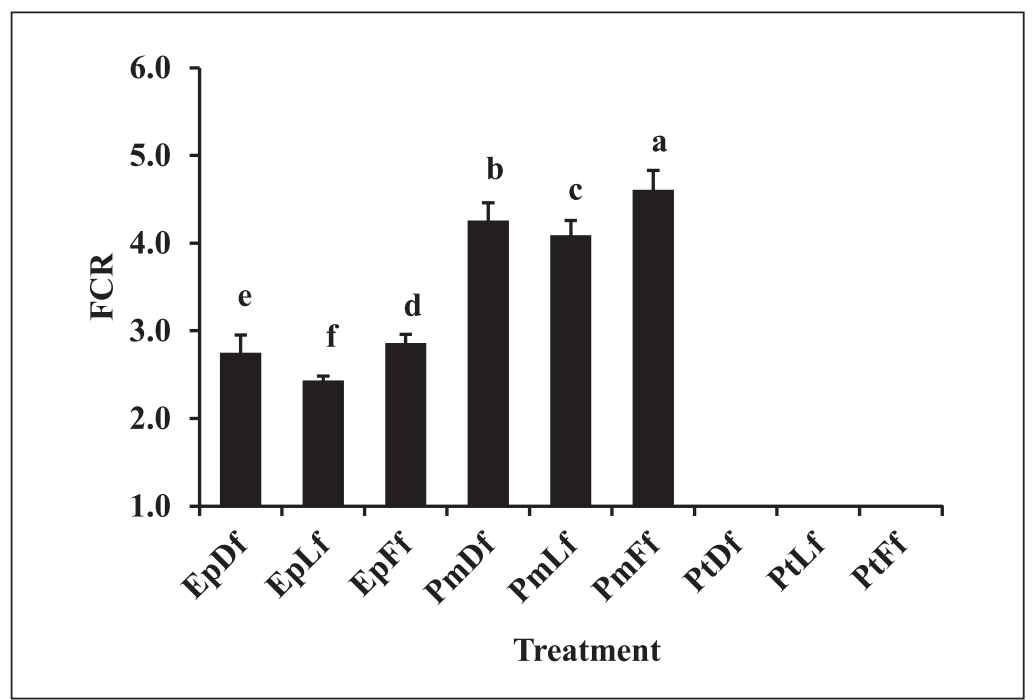

Fig. 4. Effects of different treatments on FCR of $M$. cuchia for domestication. Different letters indicate significant variations in FCR fish in different treatments $\mathrm{P}<0.05$. Error bar $= \pm \mathrm{SD}$.

highest lower FCR was in EpLf than others (Figure 4 ), indicating that this fish prefers to consume running live fish. Surprisingly, mud eel did not accept any types of feed in PtDf, PtLf and PtFf, where they reared in mud free bottom circular tank, for this reason it was not possible to measure FCR in treatments PtDf, PtLf and PtFf. Therefore, this result indicates that mud is the most essential medium for mud eel culture and domestication.

\section{Feed conversion efficiency}

The results revealed that FCE was significantly $(\mathrm{P}<0.05)$ higher in EpLf than others and the highest value of FCE was found in EpLf, that was $35.75 \pm$ $1.2 \%$ and the lowest value of FCE was $21.7 \pm 4.3 \%$ in PmFf (Figure 5). The FCE values of PtDf, PtLf and PtFf could not be measured (Figure 5). This result denotes that rearing environments is the key factor for domestication of mud eel because 


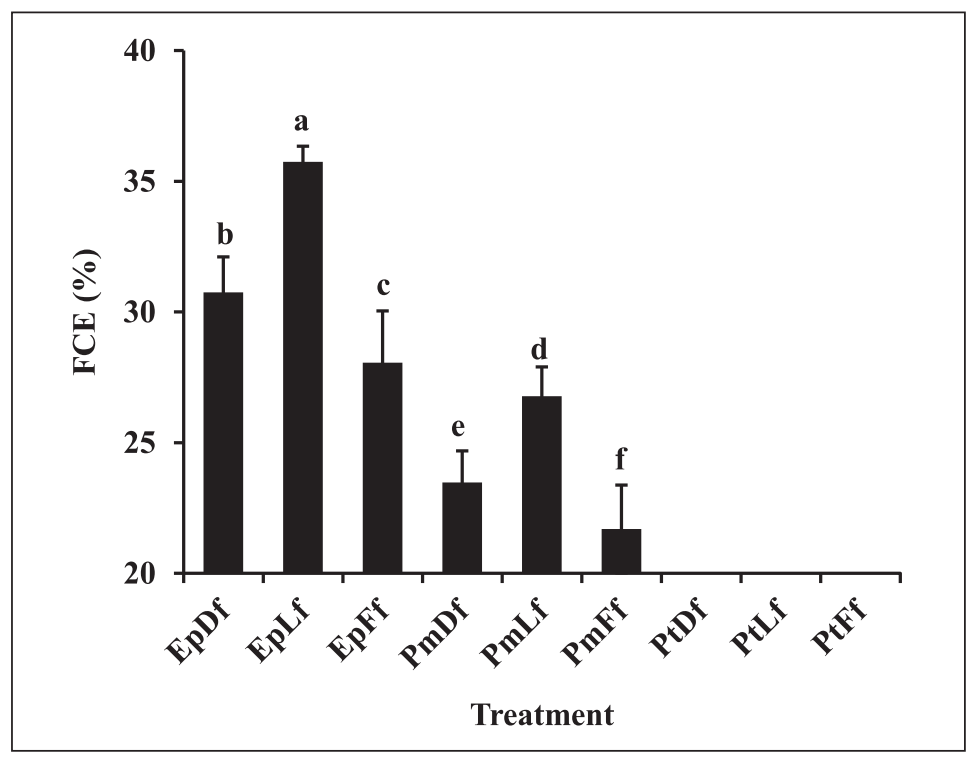

Fig. 5. Effects of different treatments on FCE of M. cuchia for domestication Different letters indicate significant variations in FCR fish in different treatments $\mathrm{P}<0.05$. Error bar $= \pm \mathrm{SD}$.

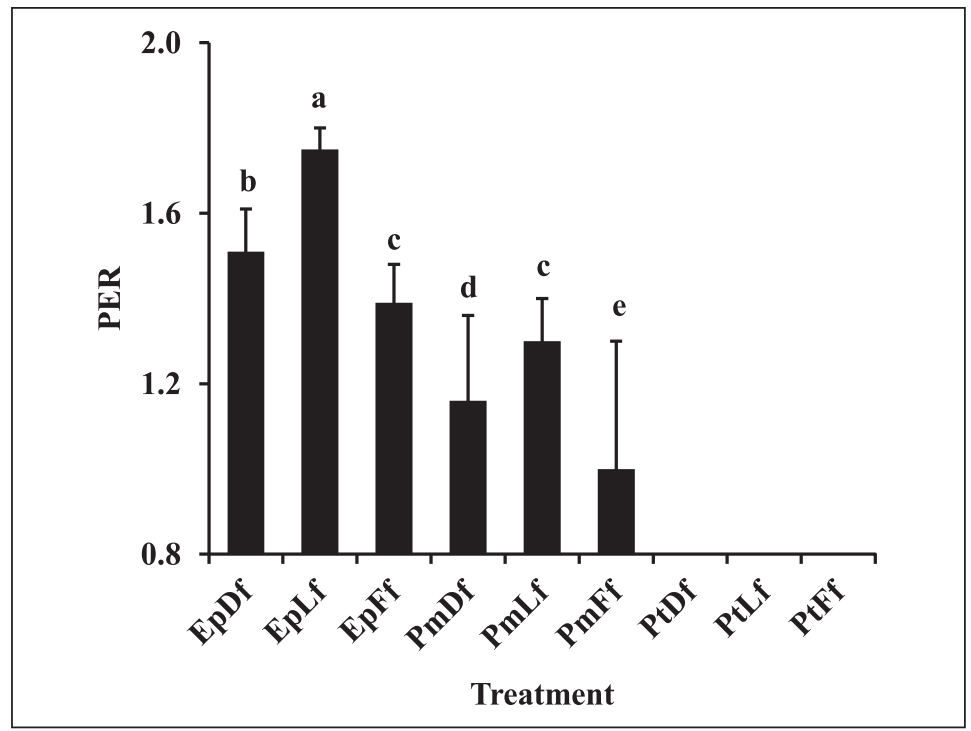

Fig. 6. Effects of different treatments on PER of M. cuchia for domestication. Different letters indicate significant variations in PER fish in different treatments $\mathrm{P}<0.05$. Error bar $= \pm \mathrm{SD}$.

M. cuchia might accept any type of natural food in earthen ponds and showed better growth performances than plastic tanks.

\section{Protein efficiency ratio}

The PERs were found to be different among the treatments. This might be due to the effects of rearing environments and the PER is dependent on percentage of protein supplied. The highest value of PER was found to be $1.75 \pm 0.02$ in EpLf with $20.30 \%$ protein level where mud eel reared in earthen ponds with small live fish and the lowest value of PER with was $1.0 \pm 0.11 \mathrm{in} P \mathrm{mFf}$ where mud eel reared in muddy bottom circular tank with formulated feed (Figure 6). The results revealed that the PER of EpLf was significantly higher $(\mathrm{P}<0.05)$ than others. These results suggest that, live fish can provide essential amino acid requirement in $M$. cuchia effectively only in earthen ponds.

\section{Water quality parameters}

The water quality parameters including temperature, $\mathrm{pH}$ and $\mathrm{DO}$ were recorded during the experimental period as shown in Table 3 . There were no fluctuations of water quality parameters among the treatments throughout the study period. 
Table 3. Observation of water quality parameters in different treatments of $M$. cuchia for domestication. Values are mean $\pm \operatorname{SD}(N=3)$

\begin{tabular}{|c|c|c|c|c|c|c|c|c|}
\hline \multirow{2}{*}{ Treatments } & \multirow{2}{*}{ Parameters } & \multirow{2}{*}{ Periods } & \multicolumn{6}{|c|}{ Number of sampling } \\
\hline & & & Initial & $1 \mathrm{st}$ & 2nd & 3rd & 4th & 5th \\
\hline \multirow[t]{6}{*}{ EpDf } & ${ }^{\star}$ Temp $\left({ }^{\circ} \mathrm{C}\right)$ & Morning & $29.6 \pm 0.07$ & $29.1 \pm 0.14$ & $28.6 \pm 0.07$ & $29.7 \pm 0.14$ & $29.5 \pm 0.13$ & $29.5 \pm 0.03$ \\
\hline & & Evening & $29.8 \pm 0.12$ & $29.2 \pm 0.11$ & $28.7 \pm 0.09$ & $29.8 \pm 0.06$ & $29.7 \pm 0.08$ & $29.8 \pm 0.06$ \\
\hline & $\mathrm{pH}$ & Morning & $6.5 \pm 0.20$ & $6.7 \pm 0.10$ & $6.1 \pm 0.30$ & $6.2 \pm 0.07$ & $6.4 \pm 0.09$ & $6.8 \pm 0.14$ \\
\hline & & Evening & $6.5 \pm 0.16$ & $6.7 \pm 0.11$ & $6.1 \pm 0.20$ & $6.2 \pm 0.05$ & $6.4 \pm 0.08$ & $6.8 \pm 0.20$ \\
\hline & DO (mg/l) & Morning & $4.5 \pm 0.10$ & $5.2 \pm 0.30$ & $4.8 \pm 0.20$ & $4.4 \pm 0.20$ & $4.9 \pm 0.14$ & $5.1 \pm 0.04$ \\
\hline & & Evening & $4.7 \pm 0.15$ & $5.5 \pm 0.25$ & $4.9 \pm 0.23$ & $4.5 \pm 0.15$ & $5.2 \pm 0.10$ & $5.4 \pm 0.12$ \\
\hline \multirow[t]{6}{*}{ EpLf } & Temp $\left({ }^{\circ} \mathrm{C}\right)$ & Morning & $29.3 \pm 0.21$ & $29.1 \pm 0.18$ & $28.3 \pm 0.21$ & $29.1 \pm 0.07$ & $29.1 \pm 0.12$ & $29.4 \pm 0.10$ \\
\hline & & Evening & $29.5 \pm 0.14$ & $29.3 \pm 0.24$ & $28.6 \pm 0.13$ & $29.3 \pm 0.11$ & $29.4 \pm 0.09$ & $29.6 \pm 0.16$ \\
\hline & $\mathrm{pH}$ & Morning & $6.4 \pm 0.30$ & $6.3 \pm 0.10$ & $6.1 \pm 0.07$ & $6.9 \pm 0.10$ & $6.5 \pm 0.04$ & $6.6 \pm 0.11$ \\
\hline & & Evening & $6.4 \pm 0.22$ & $6.3 \pm 0.09$ & $6.1 \pm 0.05$ & $6.9 \pm 0.09$ & $6.5 \pm 0.05$ & $6.6 \pm 0.07$ \\
\hline & DO (mg/l) & Morning & $4.5 \pm 0.50$ & $5.0 \pm 0.70$ & $4.8 \pm 1.20$ & $4.6 \pm 0.90$ & $4.8 \pm 0.14$ & $5.0 \pm 0.07$ \\
\hline & & Evening & $4.8 \pm 0.33$ & $5.2 \pm 0.52$ & $5.1 \pm 0.78$ & $4.8 \pm 0.50$ & $5.1 \pm 0.22$ & $5.4 \pm 0.24$ \\
\hline \multirow[t]{6}{*}{ EpFf } & Temp $\left({ }^{\circ} \mathrm{C}\right)$ & Morning & $29.4 \pm 0.42$ & $29.1 \pm 0.12$ & $28.4 \pm 0.21$ & $29.5 \pm 0.14$ & $29.1 \pm 0.10$ & $29.3 \pm 0.09$ \\
\hline & & Evening & $29.6 \pm 0.56$ & $29.2 \pm 0.15$ & $28.6 \pm 0.32$ & $29.7 \pm 0.09$ & $29.2 \pm 0.06$ & $29.5 \pm 0.16$ \\
\hline & $\mathrm{pH}$ & Morning & $6.2 \pm 0.20$ & $6.1 \pm 0.07$ & $6.4 \pm 0.40$ & $6.2 \pm 0.60$ & $6.3 \pm 0.44$ & $6.5 \pm 0.06$ \\
\hline & & Evening & $6.2 \pm 0.14$ & $6.1 \pm 0.09$ & $6.4 \pm 0.25$ & $6.2 \pm 0.45$ & $6.3 \pm 0.12$ & $6.5 \pm 0.15$ \\
\hline & DO (mg/l) & Morning & $4.8 \pm 0.20$ & $4.9 \pm 0.20$ & $4.8 \pm 0.70$ & $4.4 \pm 0.80$ & $4.9 \pm 0.40$ & $5.0 \pm 0.02$ \\
\hline & & Evening & $5.2 \pm 0.13$ & $5.0 \pm 0.08$ & $5.1 \pm 0.45$ & $4.5 \pm 0.32$ & $5.2 \pm 0.54$ & $5.3 \pm 0.09$ \\
\hline \multirow[t]{6}{*}{ PmDf } & Temp $\left({ }^{\circ} \mathrm{C}\right)$ & Morning & $29.1 \pm 0.35$ & $26.1 \pm 1.34$ & $28.1 \pm 0.21$ & $29.6 \pm 0.14$ & $28.5 \pm 0.90$ & $28.3 \pm 1.14$ \\
\hline & & Evening & $29.3 \pm 0.24$ & $26.4 \pm 0.81$ & $28.3 \pm 0.52$ & $29.7 \pm 0.42$ & $28.6 \pm 0.45$ & $28.5 \pm 0.67$ \\
\hline & $\mathrm{pH}$ & Morning & $6.9 \pm 0.07$ & $6.7 \pm 0.60$ & $6.8 \pm 0.20$ & $6.5 \pm 0.30$ & $6.4 \pm 0.20$ & $6.8 \pm 0.08$ \\
\hline & & Evening & $6.9 \pm 0.05$ & $6.7 \pm 0.14$ & $6.8 \pm 0.17$ & $6.5 \pm 0.14$ & $6.4 \pm 0.13$ & $6.8 \pm 0.09$ \\
\hline & DO (mg/l) & Morning & $4.9 \pm 0.30$ & $5.2 \pm 0.20$ & $4.7 \pm 0.07$ & $4.4 \pm 0.20$ & $4.8 \pm 0.13$ & $5.1 \pm 0.02$ \\
\hline & & Evening & $5.3 \pm 0.45$ & $5.4 \pm 0.16$ & $4.9 \pm 0.08$ & $4.7 \pm 0.09$ & $4.9 \pm 0.18$ & $5.3 \pm 0.05$ \\
\hline \multirow[t]{6}{*}{ PmLf } & Temp $\left({ }^{\circ} \mathrm{C}\right)$ & Morning & $29.6 \pm 0.35$ & $29.4 \pm 0.21$ & $28.2 \pm 0.14$ & $28.7 \pm 0.35$ & $29.1 \pm 0.20$ & $28.5 \pm 0.98$ \\
\hline & & Evening & $29.8 \pm 0.16$ & $29.6 \pm 0.14$ & $28.5 \pm 0.11$ & $28.9 \pm 0.27$ & $29.3 \pm 0.25$ & $28.7 \pm 0.64$ \\
\hline & $\mathrm{pH}$ & Morning & $6.5 \pm 0.07$ & $6.8 \pm 0.10$ & $6.0 \pm 0.10$ & $6.3 \pm 0.10$ & $6.1 \pm 0.88$ & $6.7 \pm 0.14$ \\
\hline & & Evening & $6.5 \pm 0.03$ & $6.8 \pm 0.08$ & $6.0 \pm 0.14$ & $6.3 \pm 0.09$ & $6.1 \pm 0.15$ & $6.7 \pm 0.08$ \\
\hline & DO (mg/l) & Morning & $4.3 \pm 1.20$ & $4.2 \pm 0.40$ & $4.8 \pm 0.50$ & $4.6 \pm 0.20$ & $4.7 \pm 0.56$ & $4.4 \pm 0.67$ \\
\hline & & Evening & $4.6 \pm 0.40$ & $4.4 \pm 0.39$ & $5.0 \pm 0.26$ & $4.7 \pm 0.83$ & $5.0 \pm 0.24$ & $4.7 \pm 0.26$ \\
\hline \multirow[t]{6}{*}{$\mathrm{PmFf}$} & Temp $\left({ }^{\circ} \mathrm{C}\right)$ & Morning & $28.7 \pm 1.06$ & $29.1 \pm 0.17$ & $28.3 \pm 0.07$ & $28.7 \pm 0.14$ & $29.1 \pm 0.14$ & $28.5 \pm 1.04$ \\
\hline & & Evening & $28.9 \pm 0.37$ & $29.4 \pm 0.15$ & $28.5 \pm 0.12$ & $28.9 \pm 0.24$ & $29.3 \pm 0.17$ & $28.7 \pm 0.58$ \\
\hline & $\mathrm{pH}$ & Morning & $6.4 \pm 0.20$ & $6.1 \pm 0.60$ & $6.1 \pm 0.30$ & $6.5 \pm 0.07$ & $6.4 \pm 0.64$ & $6.7 \pm 0.40$ \\
\hline & & Evening & $6.4 \pm 0.13$ & $6.1 \pm 0.06$ & $6.1 \pm 0.23$ & $6.5 \pm 0.14$ & $6.4 \pm 0.28$ & $6.7 \pm 0.19$ \\
\hline & DO (mg/l) & Morning & $4.6 \pm 0.50$ & $5.0 \pm 0.20$ & $4.8 \pm 0.40$ & $4.5 \pm 0.07$ & $4.4 \pm 0.14$ & $4.9 \pm 0.10$ \\
\hline & & Evening & $4.8 \pm 0.39$ & $5.2 \pm 0.82$ & $5.1 \pm 0.92$ & $4.7 \pm 0.39$ & $4.7 \pm 0.92$ & $5.2 \pm 0.17$ \\
\hline \multirow[t]{6}{*}{ PtDf } & Temp $\left({ }^{\circ} \mathrm{C}\right)$ & Morning & $28.9 \pm 0.14$ & $29.1 \pm 0.28$ & $28.6 \pm 0.35$ & $29.3 \pm 0.42$ & $29.1 \pm 0.06$ & $28.5 \pm 0.89$ \\
\hline & & Evening & $29.1 \pm 0.46$ & $29.4 \pm 0.24$ & $28.8 \pm 0.39$ & $29.6 \pm 0.23$ & $29.3 \pm 0.16$ & $28.7 \pm 0.35$ \\
\hline & $\mathrm{pH}$ & Morning & $6.3 \pm 0.60$ & $6.2 \pm 0.30$ & $6.1 \pm 0.20$ & $6.2 \pm 0.50$ & $6.3 \pm 0.14$ & $6.5 \pm 0.09$ \\
\hline & & Evening & $6.3 \pm 0.16$ & $6.2 \pm 0.13$ & $6.1 \pm 0.07$ & $6.2 \pm 0.15$ & $6.3 \pm 0.09$ & $6.5 \pm 0.06$ \\
\hline & DO (mg/l) & Morning & $4.5 \pm 1.20$ & $5.1 \pm 0.70$ & $4.8 \pm 0.20$ & $4.4 \pm 0.70$ & $4.9 \pm 0.50$ & $4.7 \pm 0.30$ \\
\hline & & Evening & $4.8 \pm 0.78$ & $5.3 \pm 0.34$ & $5.1 \pm 0.32$ & $4.7 \pm 0.62$ & $5.2 \pm 0.16$ & $4.9 \pm 0.28$ \\
\hline \multirow[t]{6}{*}{ PtLf } & Temp $\left({ }^{\circ} \mathrm{C}\right)$ & Morning & $29.2 \pm 0.05$ & $29.1 \pm 0.10$ & $28.6 \pm 1.14$ & $29.3 \pm 0.08$ & $28.5 \pm 1.01$ & $28.5 \pm 1.14$ \\
\hline & & Evening & $29.4 \pm 0.26$ & $29.2 \pm 0.19$ & $28.9 \pm 0.91$ & $29.6 \pm 0.17$ & $28.7 \pm 0.63$ & $28.8 \pm 0.57$ \\
\hline & $\mathrm{pH}$ & Morning & $6.0 \pm 0.02$ & $5.7 \pm 0.09$ & $5.9 \pm 0.10$ & $6.1 \pm 0.74$ & $6.0 \pm 0.34$ & $6.2 \pm 0.10$ \\
\hline & & Evening & $6.0 \pm 0.08$ & $5.7 \pm 0.15$ & $5.9 \pm 0.17$ & $6.1 \pm 0.35$ & $6.0 \pm 0.24$ & $6.2 \pm 0.03$ \\
\hline & DO (mg/l) & Morning & $4.1 \pm 0.14$ & $4.2 \pm 0.04$ & $4.5 \pm 0.24$ & $4.2 \pm 0.30$ & $4.7 \pm 0.09$ & $4.1 \pm 0.18$ \\
\hline & & Evening & $4.3 \pm 0.19$ & $4.5 \pm 0.11$ & $4.8 \pm 0.19$ & $4.4 \pm 0.24$ & $5.0 \pm 0.18$ & $4.3 \pm 0.14$ \\
\hline \multirow[t]{6}{*}{$\mathrm{PtFf}$} & Temp $\left({ }^{\circ} \mathrm{C}\right)$ & Morning & $28.6 \pm 1.02$ & $28.1 \pm 0.88$ & $28.6 \pm 1.14$ & $28.7 \pm 0.74$ & $28.5 \pm 0.94$ & $27.5 \pm 0.70$ \\
\hline & & Evening & $28.7 \pm 0.97$ & $28.4 \pm 0.58$ & $28.9 \pm 0.46$ & $28.9 \pm 0.76$ & $28.8 \pm 0.34$ & $27.8 \pm 0.34$ \\
\hline & $\mathrm{pH}$ & Morning & $6.0 \pm 0.08$ & $5.9 \pm 0.04$ & $5.8 \pm 0.30$ & $6.0 \pm 0.54$ & $6.1 \pm 0.52$ & $5.9 \pm 0.30$ \\
\hline & & Evening & $6.0 \pm 0.04$ & $5.9 \pm 0.08$ & $5.8 \pm 0.24$ & $6.0 \pm 0.18$ & $6.1 \pm 0.23$ & $5.9 \pm 0.01$ \\
\hline & DO (mg/l) & Morning & $5.5 \pm 0.04$ & $5.2 \pm 0.06$ & $5.0 \pm 0.35$ & $5.2 \pm 0.39$ & $5.0 \pm 0.54$ & $5.1 \pm 0.44$ \\
\hline & & Evening & $5.7 \pm 0.24$ & $5.5 \pm 0.21$ & $5.2 \pm 0.52$ & $5.4 \pm 0.25$ & $5.3 \pm 0.42$ & $5.3 \pm 0.12$ \\
\hline
\end{tabular}




\section{DISCUSSION}

The present study was conducted to determine the suitable environment for domestication of M. cuchia for available seed production. In this study, the small live fish feed (protein 20.30\%) significantly developed the domestication technique of M. cuchia in the earthen pond. Significantly, the highest growth performance was recorded in earthen ponds with polythene sheet with supplied small live fish, implying that mud might be the best habitat for the species. This species also might prefer live small fish for continuing the life cycle. The highest growth performances were found in earthen ponds due to having the availability of natural foods such as tubifex, worms, detritus so on in the pond water. In addition, it might be the quiet environment and the fish might come by suitable muddy space to make them comfortable and they can easily burrow in the bottom mud whenever they need. Further study could be conducted to confirm the availability of these natural foods during mud eel culture. Conversely, the weight loss might be due to the use of mud free rearing environment in plastic tank as their rearing condition was not appropriate therefore, they did not consume any type of foods. Although the volume of each plastic tank was about three times smaller than the earthen ponds in our study, the plastic tanks were well equipped with aerator system rather than the earthen ponds. Actually, the freshwater mud eels were well adapted with any adverse environment because they could inhabit small area with high stocking density due to having their some exceptional physiological activities particularly respiratory organs (Singh et al., 1989; Alam et al., 2012). This species has dual systems of oxygen uptake for respiration (Liem, 1967) and this species also has a pair of air-breathing organs on two sides of head (Jhingran \& Talwar, 1991). These results indicated that inhabiting space is not a factor for their healthy life.

Miah et al. (2015) observed that, earthen ditches fed with the earthworms and small live fish (tilapia) were the best among all other environment for better growth performance of freshwater mud eel, which is in consistent with the present findings. However, Narejo et al. (2003a; 2003b) found better growth of young $M$. cuchia in cemented cistern using water hyacinth, which is not similar to our results. Narejo et al. (2003a) reported that this young fish, which were cultured in cemented cisterns with dead fish had well growth, however, this study completely disagrees with some previous findings in freshwater mud eel as well as other eel fish. This present study showed that small live fishes were effective for better growth performance of M. cuchia. The mean survival rate in the present study was $98 \pm 0.8 \%$, $72.3 \pm 1.53 \%$ and $54.3 \pm 4.12 \%$ in earthen ponds with polythene sheet, plastic tank with mud, and plastic tank without mud respectively. Narejo et al. (2003b) found that survival rate of M. cuchia was $80 \%$ reared in cemented cistern with mud and $100 \%$ was reared in cemented cistern with water hyacinth. The findings of present study are different from Narejo et al. (2003b). On the other hand, Miah et al. (2015) reported that the survival rate of this species was $92.5 \%$ reared in earthen ditches with live fish, which is closely related with the present findings.

The SGR of fish were significantly higher in the earthen ponds with live small fish than the plastic tanks, which might be due to the nature of the environment as well as the fish in the earthen pond might feel less disturbance. Our results were supported by Rahman et al. (2018), who showed that the earthen pond significantly enhanced the growth of young mud eel. Actually, the eel fishes are slow growing (Nasar, 1997) and are very sensitive to the slightest disturbance. Moreover, the muddy environment is suitable for their physiological activities (Liem, 1967, Shingh et al., 1989), which might be a good indicator for the growth performance of this fish. This species also can spend their daytime under the mud or having burrowing habit (Nasar, 1997).

In the present study, the lowest FCR obtained in earthen ponds with polythene sheet with different diets having different levels of protein. Interestingly, low FCR at different levels of protein and formulated feed with $30 \%$ protein clearly reflects that these diets were utilized more efficiently in earthen ponds. Whereas, the supplied feeds did not use properly in the plastic tanks. Idris et al. (2015) found that the lowest FCR was found in live feeds treated study. Chakraborty et al. (2013) reported the lowest FCR of M. cuchia was found in rice field than in ponds. This finding suggested that FCR is also dependent on rearing environment. The average FCR for glass eels generally lies below 1.0 and sometimes the FCR of growing eels range from 1.2 to 1.4 (Cremer, 2009; Rahman et al., 2018). The value of FCE was higher in EpLf than any other treatments. Sunde et al. (2004) found that FCE was significantly different between the high and low quality feed groups in salmon, where the difference between the high and low feed protein qualities was large.

In the present study the highest value of PER was found in EpLf with $20.30 \%$ protein level where mud eel reared in earthen ponds with small live fish and the lowest value of PER was found in PmFf. Bae et al. (2012) revealed that $0.5 \%$ dietary priopiols can increase the PER of the fish. Moreover, there are no established data on PER of M. cuchia, so it is not possible to compare the value of PER of the present study with the previous findings. 


\section{CONCLUSION}

The declination of its resources in recent years has resulted in an urgent need for technology development in artificial seedlings production of M. cuchia for the farming industry in Bangladesh. Since the life history of this species is mysterious, induced breeding of mud eel has long been regarded as an extremely difficult task. The present study suggests that it may not be possible to culture mud eel in confined environment without mud and live foods. The present study provides baseline information on domestication of this fish that would be helpful for the future researchers and also save the fish from extinction. Further research might be carried out on hormonal signaling and also must identify the receptor protein, which is inhibiting the induced breeding of this fish.

\section{ACKNOWLEDGEMENTS}

This research was supported by Ministry of Science and Technology, Bangladesh (Project Grant No. MoST BS 382; 2014-2015) and referred to the Department of Genetics \& Fish Breeding, BSMRAU to M.A. Salam. Thanks to UKM for the processing fee of this article through Publication Incentive grant “GP-2019-K019059". We are grateful to the fish suppliers and the fishermen for their help in providing M. cuchia samples.

\section{REFERENCES}

Alam, J., Rashid, H., Mithu, M. \& Hossain, M.A.R. (2012). Study of reproductive physiology of mud eel Monopterus cuchia for artificial propagation. In 5th Fisheries conference and research fair, $\mathrm{p} 1$.

AOAC (Association of Official Analytical Chemists). (1980). Official Methods of Analysis of the Association of Official Analytical Chemists. Ed. W. Hoewitz. $13^{\text {th }}$ ed. Washington D.C., pp.78.

Bae, J., Park, G.H. \& Lee, J. (2012). Effects of dietary propolis supplementation on growth performance, immune responses, disease resistance and body composition of juvenile eel, Anguilla Japonica. Aquaculture International, 20: 513-523.

Chakraborty, B.K., Azad, S.A., Barmon, B. \& Farque, A.M.O. (2013). Fecundity and gonado somatic index of gangetic mud eel, Monopterus Cuchia (Hamilton, 1822). Bangladesh Journal of Zoology, 41: 165-172.
Cremer, M.C. (2009). Eel culture in the Philippines. Journal of the World Aquaculture Society, 7: 129-136.

FAO. (2005). Fishery Statistics; Aquaculture Production (2004). FAO Fisheries series No. 72/ FAO Statistics No.185, Rome, Italy.

Hasan, M.T., Jang, W.J., Lee, S., Kim, K.W., Lee, B.J., Han, H.S., Bai, S.C. \& Kong, I.S. (2018). Effect of $\beta$-glucooligosaccharides as a new prebiotic for dietary supplementation in olive flounder (Paralichthys olivaceus) aquaculture. Aquaculture Research, 49(3): 310-1319.

Idris, A.P.S., Mallawa, A. \& Saade, E. (2015). The effect of different doses snails as a source of protein feed on the growth and eel fish survival (Anguilla sp.). International Journal of Scientific and Research Publications, 5(6): $1-4$.

Jhingran, V.G. \& Talwar, P.K. (1991). Inland fishes of India and adjacent countries. Oxford and IBH Publishing Co. Pvt. Ltd. Calcutta. pp. 1541.

Kakati, L.N., Bendong, A.O. \& Doulo, V. (2006). Indigenous knowledge of zootherapeutic use of vertebrate origin by the Ao Tribe of Nagaland. Journal of Human Ecology, 19: 163-167.

Liem, K.F. (1967). Functional morphology of the integumentary, respiratory, and digestive systems of the synbranchoid fish Monopterus albus. Copeia, 375-388.

Miah, M.F., Ali, H., Jannat, E., Naser, M.N. \& Ahmed, M.K. (2015). Rearing and production performance of freshwater mud eel, Monopterus cuchia in different culture regimes. Advances in Zoology and Botany, 3(3): 42-49.

Mishra, N., Pandey, P.K. \& Datta. J.S. (1977). Haematological parameters of an air-breathing mud eel, Monopterus cuchia (Ham.) (Amphipnoidae; Pisces). Journal of Fish Biology, 10(6): 567-573.

Narejo, N.T., Rahmatullah, S.M. \& Rashid, M.M. 2003a. Effect of different feeds on growth, survival and production of freshwater mud eel, Monopterus cuchia (Hamilton). Indian Journal of Fisheries, 50(4): 473-477.

Narejo, N.T., Rahmatullah, S.M. \& Rashid, M.M. (2003b). Effect of different shelters on growth, survival and production of freshwater mud eel, Monopterus cuchia (Hamilton) reared in cemented cisterns of BAU, Mymensingh, Bangladesh. Pakistan Journal of Biological Sciences, 6(20): 1753-1757.

Nasar, S.S.T. (1997). Backyard Eel Culture: International Institute of Rural Reconstruction, Silag, Cavity, Philippines. pp. 88. 
Pankhurst, N.W. (1982). Relation of visual changes to the onset of sexual maturation in the European eel Anguilla anguilla (L.). Journal of Fish Biology, 21(2): 27-140.

Park, Y., Kim, H., Won, S., Hamidoghli, A., Hasan, M.T., Kong, I.S. \& Bai, S.C. (2020). Effects of two dietary probiotics (Bacillus subtilis or licheniformis) with two prebiotics (mannan or fructo oligosaccharide) in Japanese eel, Anguilla japonica. Aquaculture Nutrition, 26(2): 316-327.

Rahman, M.M., Hossain, M.M.M., Billah, M.M. Asif, A.A. \& Ferdous, J. (2018). Growth of freshwater mud eel (Monopterus cuchia) in different water condition, feeds and probiotics. International Journal of Business, Social and Scientific Research, 7(1): 10-17.

Saikia, K. \& Ahmed, R. (2012). Wetland fish biodiversity of Majuli River Island (India) and their medicinal values. The Clarion, 1(2): 8186.

Salam, M.A., Khan, M.A., Rahman, M.M., Kabir, M.S. \& Rahmatullah, S.M. (2009). Effect of water depth on growth and survival rate of freshwater mud eel, Monopterus cuchia (Himilton) reared in the cemented cisterns. Bangladesh Journal of Progressive Science and Technology, 7: 117-120.
Sayeed, M.A., Hossain, M.A.R., Wahab, M.A., Hasan, M.T., Simon, K.D. \& Mazumder, S.K. (2015). Water and sediment quality parameters in the Chalan Beel, the largest wetland of Bangladesh. Chinese Journal of Oceanology and Limnology, 33(4): 895-904.

Singh, B.N., Towheed, M.A. \& Munshi, J.D. (1989). Respiratory adaptations in the larvae of Monopterus cuchia (Ham.). Journal of Fish Biology, 34(4): 637-638.

Sunde, J., Eiane, S.A., Rustad, A., Jensen, H.B., Opstvedt, J.E., Venturini, G. \& Torrissen, K.R. (2004). Effect of fish feed processing conditions on digestive protease activities, free amino acid pools, feed conversion efficiency and growth in Atlantic Salmon (Salmo salar L.). Aquaculture Nutrition, 10: 261-277.

Tanaka, H., Kagawa, H., Ohta, H., Unuma, T. \& Nomura, K. (2003). The first production of glass eel in captivity: fish reproductive physiology facilitates great progress in aquaculture. Fish Physiology and Biochemistry, 28(1-4): 493-497. 